Jurnal Penelitian dan Evaluasi Pendidikan

\title{
PENGEMBANGAN MODEL PENILAIAN KOMPREHENSIF BERBASIS PROYEK PENDIDIKAN KEWIRAUSAHAAN TERINTEGRASI DI SMK
}

\author{
Endang Mulyani \\ Fakultas Ekonomi UNY \\ endangmulyani_uny@yahoo.com
}

\begin{abstract}
Abstrak
Tujuan penelitian ini adalah mengembangkan model penilaian komprehensif berbasis proyek pendidikan kewirausahaan terintegrasi di SMK. Pengembangan model penilaian ini menggunakan Four-D model meliputi tahap define, design, develop, dan disseminate. Rancangan model dalam penelitian ini belum sampai pada tahap disseminate, sehingga hanya meliputi tiga tahapan yaitu tahap define, design, dan develop.Subjek penelitian adalah siswa kelas XI program studi penjualan, guru ekonomi, dan guru kewirausahaan. Teknik pengumpulan data yang digunakan adalah angket, observasi, dokumentasi, dan tes. Teknik analisis data yang digunakan adalah teknik analisis diskriptif,dan Confirmatory Factor Analysis (CFA). Hasil penelitian adalah sebagai berikut: 1) dilihat dari hasil analisis penilaian pakar menunjukan bahwa model penilaian secara umum termasuk dalam kategori baik dan dapat digunakan; 2) dilihat dari hasil analisis CFA, menunjukkan adanya konsistensi, hal ini terbukti dari hasil pengujian model pada uji coba terbatas dan skala luas sama-sama menghasilkan model fit pada taraf signifikansi 5\%.
\end{abstract}

Kata kunci: model, penilaian, komprehensif, proyek, pendidikan kewirausahaan 


\title{
DEVELOPING A COMPREHENSIVE ASSESSMENT MODEL BASED ON AN INTREGATED ENTREPRENEURSHIP EDUCATION PROJECT IN VOCATIONAL SECONDARY SCHOOLS
}

\author{
Endang Mulyani \\ Fakultas Ekonomi UNY \\ endangmulyani_uny@yahoo.com
}

\begin{abstract}
The main objective of this study is to develop a comprehensive assessment model based on an integrated entrepreneurship education project in vocational secondary schools. This developed assessment model employed the Four-D model, consisting of define, design, develop, and disseminate stages. The model in this study did not take the disseminate stage; it only took three stages, namely the define, design, and develop stages. The research subjects comprised Year XI students of the Sales Study Program, economics teachers, and entrepreneurship teachers. The data were collected through questionnaires, observations, documents, and tests. The data were analyzed using the descriptive analysis technique, and Confirmatory Factor Analysis (CFA). The research findings are as follows 1) based on the results of the analysis of the evaluation by experts, the assessment model in general is in the good category and is applicable; 2) based on the results of the analysis using CFA, there is a consistency, indicated by the model testing in the small-scale and large-scale tryouts revealing that the model fits the empirical data; besides, all constructs designed to measure variables are significant at alpha 5\%
\end{abstract}

Keywords: model, assessment, comprehensive, project, entrepreneurship education 


\section{Pendahuluan}

Dalam UU No 20 Tahun 2003 Tentang Sistem Pendidikan Nasional pada Pasal 3 disebutkan bahwa pendidikan nasional bertujuan untuk mengembangkan potensi peserta didik agar menjadi manusia yang beriman dan bertakwa kepada Tuhan Yang Maha Esa, berakhlak mulia, sehat, berilmu, cakap, kreatif, mandiri, dan menjadi warga negara yang demokratis serta bertanggung jawab. Sekolah Menengah Kejuruan (SMK) sebagai salah satu institusi yang menyiapkan tenaga kerja dituntut mampu menghasilkan lulusan sebagaimana yang diharapkan dunia kerja, yang memiliki kompetensi sesuai dengan bidang pekerjaannya, serta memiliki daya adaptasi dan daya saing yang tinggi. Untuk itu, menurut Engkoswara (1999: 22), pendidikan menengah kejuruan harus dijalankan atas dasar prinsip investasi SDM (Human Capital Investment). Hal tersebut mengandung arti bahwa semakin tinggi kualitas pendidikan yang diperoleh seseorang akan semakin produktif, sehingga selain meningkatkan produktivitas juga akan meningkatkan daya saing tenaga kerja di pasar kerja global.

Untuk mencapai tujuan tersebut, kualitas pendidikan SMK harus terus ditingkatkan. Berdasarkan hasil pengamatan penulis di tiga SMK yaitu SMK N I Depok, SMK N I Pengasih dan SMK Muhammmadiyah 2 Bantul pada penelitian pendahuluan, menunjukkan bahwa teknik penilaian di SMK juga masih dominan mengukur kemampuan kognitif, belum mengukur kemampuan yang terkait dengan kemampuan kewirausahaan. Oleh karena itu dalam penelitian ini perlu dikembangkan model penilaian komprehensif berbasis proyek pendidikan kewirausahaan terintegrasi di SMK yang mampu mengukur prestasi belajar siswa yang meliputi kemampuan akademik dan kemampuan kewirausahaan. Kemampuan akademik meliputi aspek kognitif, afektif, dan psikomotorik, sedangkan kemampuan kewirausahaan meliputi sikap, minat, dan perilaku wirausaha.

Arman Hakim Nasution (2007: 4) mendefinisikan Entrepreneur sebagai seorang inovator yang menggabungkan teknologi yang berbeda dan konsep-konsep bisnis untuk menghasilkan produk atau jasa baru yang mampu mengenali setiap kesempatan yang menguntungkan, menyusun strategi, dan yang berhasil menerapkan ide-idenya. Menurut Thomas W. 
Zimmerer dalam Suryana (2006: 10), kewirausahaan adalah hasil dari suatu disiplin serta proses sistematis penerapan kreativitas dan inovasi dalam memenuhi kebutuhan dan peluang di pasar. Seorang wirausaha harus memiliki keunggulan yang merupakan kekuatan bagi dirinya dan harus memperbaiki kelemahan agar menghasilkan keunggulan. Meredith (2006: 5) memberikan ciri-ciri seseorang yang memiliki jiwa wirausaha (entrepeneur) sebagai orang yang: 1) percaya diri, 2) berorientasi pada tugas dan hasil, 3) keberanian mengambil risiko, 4) berjiwa kepemimpinan, 5) berorientasi ke depan, dan 6) keorisinial.

Terkait dengan permasalahan penilaian, Suyanto (2001: 14) mengatakan bahwa sampai saat ini pendidikan di semua jenjang dalam pelaksanaan penilaian masih lebih mementingkan aspek kognitif, sedangkan aspek afektif masih ditelantarkan. Mengenai kelemahan penilaian pendidikan selama ini juga dikemukakan oleh Nitko (1996: 34) yang mengatakan bahwa:

1) basil-basil tes nampak tidak peka terhadap perbaikan input pendidikan dan terbadap persepsi guru dan orang tua mengenai prestasi belajar, 2) laporan hasil tes tidak menerangkan tentang pengetabuan dan keterampilan yang dipelajari oleb siswa, 3) hasil-hasil ujian memberi dasar yang rapub untuk membimbing siswa ke arah kejuruan dan penembangan karir.

Untuk mengatasi permasalahan yang terkait dengan penilaian seperti telah dikemukakan di atas, sangatlah penting untuk dikembangkan model penilaian komprehensif berbasis proyek pendidikan kewirausahaan dengan alasan karena di dalam Standar Kompetensi Lulusan (SKL) Sekolah Menengah Kejuruan (SMK) yang tercantum dalam Lampiran Peraturan Menteri Pendidikan Nasional Nomor 23 Tahun 2006, terdapat beberapa kompetensi yang mengatakan bahwa lulusan pendidikan di Sekolah Menengah Kejuruan (SMK) selain memiliki kemampuan di bidang akademik juga diharapkan memiliki kemampuan kewirausahaan. Mackeracher (1996: 24), dalam penelitiannya juga menyatakan bahwa menilai kinerja siswa melalui proyek-proyek mampu untuk menilai kemampuan kognitif, afektif dan perilaku, tetapi juga membantu untuk 
membuat instruksi yang sepenuhnya responsif terhadap kebutuhan siswa. Alasan lain yang juga memperkuat peneliti untuk mengembangkan penilaian berbasis proyek pendidikan kewirausahaan adalah bahwa penilaian ini termasuk dalam penilaian proses, dimana penilaian proses merupakan teknik penilaian yang mampu mengukur kemampuan siswa secara lebih komprehensif. Penilaian dalam proses pembelajaran merupakan suatu proses untuk mengumpulkan, menganalisis, dan menginterpretasi informasi untuk mengetahui tingkat pencapaian tujuan pembelajaran (Gronlund dan Linn, 1990: 11). Hal ini telah dibuktikan oleh Agapitus H Kaluge (2004: 25) dalam penelitiannya yang menghasilkan model penilaian proses belajar matematika yang komprehensif dan kontinu. Model penilaian ini terbukti mampu menilai aspek kognitif, afektif, dan psikomotorik siswa secara lebih akurat dan objektif sehingga memungkinkan guru atau orang tua untuk dapat mengikuti perkembangan belajar siswa secara lebih teratur dan terus menerus. Di samping itu, teknik penilaian ini juga terbukti mampu meningkatkan motivasi, tanggung jawab, dan rasa percaya diri siswa.

Terkait dengan latar belakang tersebut, pada penelitian ini akan dikembangkan model penilaian komprehensif berbasis proyek. Model penelitian ini diterapkan pada pendidikan kewirausahaan terintegrasi di SMK.

\section{Metode Penelitian}

Pengembangan model penilaian ini mengikuti prosedur pengembangan yang diajukan Thiaragajan, Semmel \& Semmel (1974: 35) yang dikenal dengan Four-D model. Tahapan dalam Four-D model meliputi empat tahap yaitu: define, design, develop, dan desseminate. Rancangan model dalam penelitian ini hanya meliputi tiga tahap. Untuk memperoleh data yang terpercaya diperlukan instrumen yang valid dan reliabel. Guna memenuhi hal tersebut, instrumen yang sudah dikembangkan tersebut perlu diuji validitas konstruknya. Secara teoretis, uji validitas konstruk sudah dilakukan dalam proses pengembangan instrumen, yaitu dengan mengembangkan definisi operasional berdasarkan teori sampai dengan 
penulisan kisi-kisi dan instrumen penelitian. Namun demikian, guna memenuhi validitas konstruk secara empiris, perlu dilakukan pengujian dengan menggunakan model Confirmatory Factor Analysis (CF $A)$.

Untuk keperluan menguji konstruk instrumen, model penilaian komprehensif berbasis proyek pendidikan kewirausahaan dirancang model Second Order Confirmatory Factor Analysis (CFA) sebagai berikut.

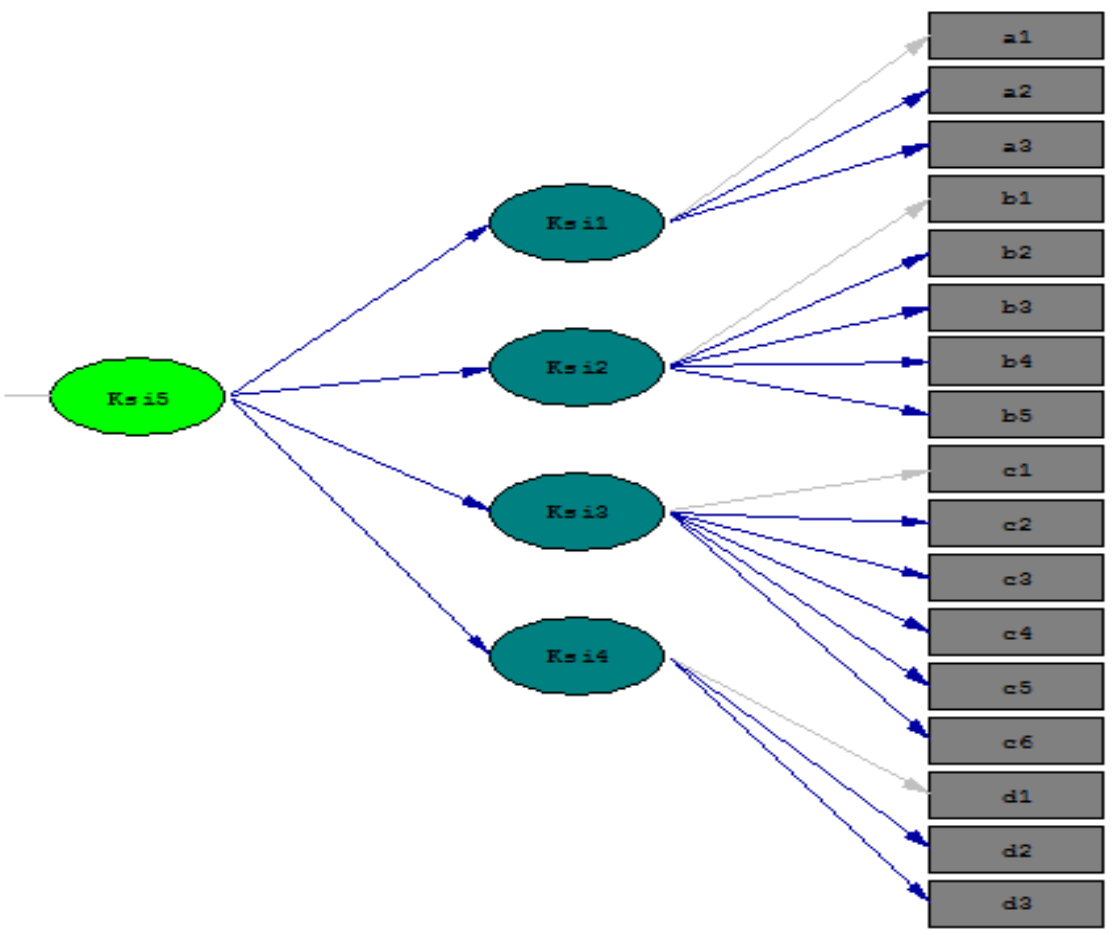

Gambar 1. Model Second Order Confirmatory Factor Analysis

Keterangan:
Ksi1 = Sikap Kewirausahaan
C1 = Kreatif
A1 = Kognitif
C2 = Inovatif
A2 = Afektif
C3 = Kerjasama
A3 = Konasi
C4 = Percaya diri 


$$
\begin{array}{llll}
\text { Ksi2 } & =\text { Minat Berwirausaha } & \text { C5 } & =\text { Pengambilan resiko } \\
\mathrm{B} 1 & =\text { Dorongan } / \text { motivasi } & \text { C6 } & =\text { Kepemimpinan } \\
\text { B2 } & =\text { Perhatian } & \text { Ksi4 } & =\text { Kemampuan Akademik } \\
\text { B3 } & =\text { Perasaan senang } & \text { D1 } & =\text { Kognitif } \\
\text { B4 } & =\text { Kemampuan } & \text { D2 } & =\text { Afektif } \\
\text { B5 } & =\text { Kesesuaian/kecocokan } & \text { D3 } & =\text { Psikomotorik } \\
\text { Ksi3 } & =\text { Perilaku Kewirausahaan } & \text { Ksi5 } & =\text { Prestasi/Hasil Belajar }
\end{array}
$$

Sebelum diimplementasikan, model penilaian yang dikembangkan dalam penelitian dilakukan uji coba. Uji coba dilakukan dua kali yaitu uji coba terbatas (SMK N 1 Depok) dan uji coba luas (SMK N 1 Depok, SMK N II Pengasih, dan SMK Muhammadiyah II. Hasil uji coba dianalisis untuk mendapatkan model yang fit. Ujicoba dilakukan dengan metode eksperimen semu dengan model pretest-postest control group desain. Subjek untuk uji coba terbatas adalah guru dan siswa SMK N I Depok kelas XI. Guru yang terlibat sebagai subyek uji coba adalah satu guru Ekonomi dan satu guru Kewirausahaan. Teknik pengumpulan data yang digunakan dalam penelitian ini berupa: observasi, angket, dokumentasi dan wawancara.Teknik analisis data dalam penelitian ini digunakan teknik analisis diskriptif dan Confirmatory Faktor Analysis (CFA)

\section{Hasil Penelitian dan Pembahasan}

1. Hasil Pengembangan Model Penilaian Komprehensif Berbasis Proyek Pendidikan Kewirausahaan Terintegrasi di SMK

Pengembangan model penilaian ini meliputi dua hal yaitu pengembangan model penilaian dan pengembangan instrumen penilaian. Untuk melihat baik/fit tidaknya model penilaian ini dilihat dari hasil analisis penilaian pakar, uji konstruk, dan keterlaksanaan model. Untuk melihat hasil pengembangan model penilaian ini akan dipaparkan hasil analisis data pada prauji coba, uji coba terbatas dan uji coba luas. 
a. Hasil Prauji Coba

Sebelum model penilaian yang telah dikembangkan diujicobakan dilakukan kegiatan praujicoba. Pada praujicoba ini, ada beberapa kegiatan yang dilakukan, hasilnya sebagai berikut.

1) Hasil Penilaian Pakar tentang Model Penilaian Komprehensif Berbasis

Proyek Pendidikan Kewirausahaan

Sebelum dilakukan validasi pakar, pada kegiatan ini dilakukan validasi internal dari model penilaian yang telah dikembangkan.Validasi internal ini dilakukan dengan diskusi kelompok terfokus di Lembaga Penelitian Universitas Negeri Yogyakarta dengan cara menghadirkan guru dari tiga SMK masing-masing dua guru yang mengampu mata pelajaran ekonomi dan kewirausahaan untuk melakukan diskusi dan melakukan review guna mendapatkan masukan dari model yang telah dikembangkan. Setelah direvisi, model ini divalidasi oleh 3 orang pakar. Dari hasil penilaian pakar tersebut, instrumen ini dinyatakan sangat baik dan dapat digunakan.

2) Hasil Validasi Pakar tentang Instrumen Penilaian Model Penilaian

Komprehensif Berbasis Proyek Pendidikan Kewirausahaan.

Instrumen penilaian model yang dikembangkan dalam penelitian ini meliputi instrumen penilaian keterlaksanaan model, tugas proyek, rubrik penilaian, dan Lembar Kerja Siswa. Berdasarkan hasil penilaian pakar, dari enam instrumen ada lima instrumen termasuk kategori sangat baik, dan satu instrumen termasuk dalam kategori baik.

\section{b. Hasil Uji Coba Terbatas}

Uji coba terbatas dilaksanakan di SMKN I Depok. Uji coba dilaksanakan pada bulan Juli 2010. Uji coba dilaksanakan selama tiga kali pertemuan, tiap pertemuan selama 2 jam pelajaran. Uji coba terbatas dilakukan di dua kelas SMK N 1 Depok, satu kelas sebagai kelas kontrol dan satu kelas lagi sebagai kelas eksperimen. Jumlah siswa yang terlibat dalam untuk uji coba terbatas ini sebanyak 72 siswa. Hasil analisis data pengembangan model penilaian komprehensif berbasis proyek pendidikan kewirausahaan pada uji coba terbatas akan dipaparkan pada uraian berikut. 
1) Hasil Uji Konstruk Model Penilaian Komprehensif Besbasis Proyek Pendidikan Kewirausahaan Pada Uji Coba Terbatas

Untuk keperluan uji konstruk model penilaian komprehensif berbasis proyek pendidikan kewirausahaan digunakan teknik analisis Confirmatory Factor Analysis (CFA) dan dianalisis dengan menggunakan SEM. Untuk keperluan analisis tersebut langkah-langkah yang perlu dilakukan adalah sebagai berikut.

a) Merancang Model Confirmatory Factor Analysis (CFA)

Untuk keperluan menguji konstruk model penilaian komprehensif berbasis proyek pendidikan kewirausahaan dirancang model Second Order Confirmatory Factor Analysis (CFA).

b) Pengujian Persyaratan Analisis dengan SEM Untuk Uji Coba terbatas

Penggunaan analisis SEM memerlukan beberapa persyaratan yang harus dipenuhi terlebih dahulu, yaitu data berdistribusi normal, dan identifikasi model. Hasil analisis uji normalitas menunjukkan bahwa nilai signifikansi (p) dari uji Kolmogorv-Smirnov untuk semua variabel lebih dari 0,05. Dengan demikian, dapat disimpulkan bahwa semua variabel memiliki data yang berdistribusi normal. Hasil analisis menunjukkan bahwa derajat bebasnya adalah 115 yang, artinya over identified. Oleh karena itu, model ini telah memenuhi syarat untuk dilakukan pengujian lebih lanjut.

c) Hasil Uji Model Penilaian Komprehensif Berbasis Proyek Pendidikan Kewirausahaan.

Untuk dapat mengetahui fit atau tidaknya model penilaian dengan data empiris, perlu melakukan penafsiran terhadap parameter yang ditemukan, terlebih dahulu harus dilihat goodness of fit dari model yang akan diuji. Hipotesis yang diuji adalah model yang dikembangkan dalam penelitian ini fit dengan model yang diperoleh dari data empiris. Dari hipotesis tersebut dilakukan pengujian secara empiris terhadap data dengan menggunakan analisis persamaan struktural (Structural Equation Model). Untuk menentukan fit tidaknya 
model digunakan criteria: 1) nilai Chi-Square yang cukup kecil dan tidak signifikan atau p lebih besar dari 0,05,2) nilai RMSEA lebih kecil dari 0,08, 3) ilai GFI lebih dari 0,90, dan 4) nilai AGFI lebih dari 0,90 .

Berdasarkan hasil pengujian model persamaan struktural, ditemukan hasil yang disajikan pada tabel berikut.

Tabel 1. Hasil Pengujian Goodness of Fit pada Uji Coba Terbatas

\begin{tabular}{|l|c|c|l|}
\hline \multicolumn{1}{|c|}{ Ukuran } & Nilai & Kriteria & \multicolumn{1}{|c|}{ Kesimpulan } \\
\hline Chi Square & 98,08 & & \\
\hline p-value & 0,87 & $>0,05$ & Fit \\
\hline RMSEA & 0,00 & $<0,08$ & Fit \\
\hline GFI & 0,86 & $>0,90$ & Cukup Fit \\
\hline AGFI & 0,81 & $>0,90$ & Cukup Fit \\
\hline
\end{tabular}

Pengujian model Second Order CFA menunjukkan bahwa kalau dilihat dari nilai Chi Square dan RMSEA maka model masuk dalam kategori fit karena nilai $\mathrm{p}>0,05$ dan RMSEA $<0,08$, sedangkan jika dilihat dari ukuran GFI dan AGFI model ini masuk dalam kategori cukup fit karena nilainya sudah lebih dari 0,80 , namun kurang dari 0,90. Simpulan GFI cukup fit didasarkan pada, nilai GFI berkisar antara 0 (poor fit) sampai 1 (perfect fit), dan nilai GFI $>=0,90$ merupakan good fit (kecocokan yang baik), sedangkan 0,80 $\leq \mathrm{GFI}<0,90$ sering disebut sebagai marginal fit (Wijayanto, 2008: 53). Hal tersebut menunjukkan bahwa model teoretis yang dihipotesiskan pada penelitian ini cocok ( fit) dengan model yang diperoleh dari data empiris, sehingga langkah selanjutnya adalah menafsirkan hasil pengujian koefisien muatan faktor/konstruk dalam model Second Order CFA ini. Hasil model empiris dari model Second Order CFA selengkapnya dapat dilihat pada Gambar 2 di bawah ini. 


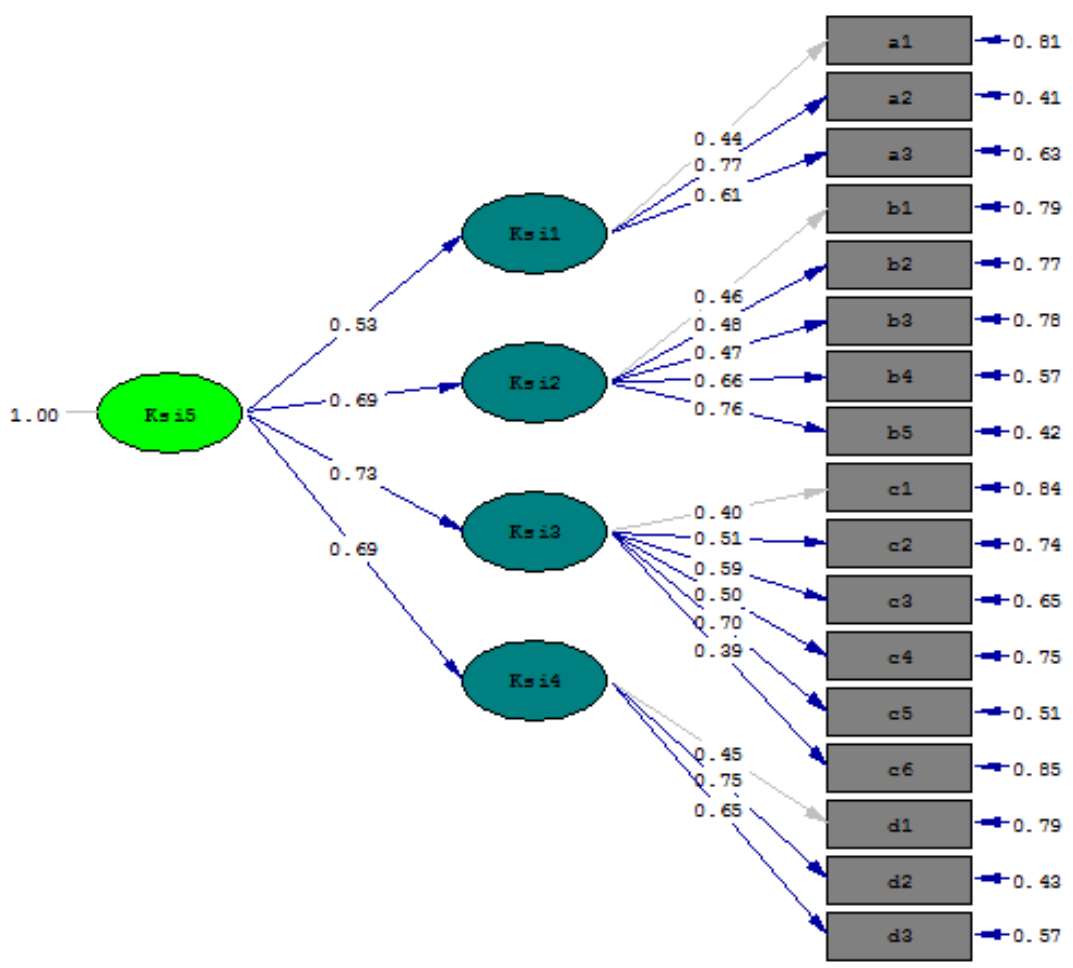

Gambar 2. Model Second Order CFA Empiris pada

Uji Coba Terbatas $(\mathrm{N}=72)$

Setelah dilakukan uji konstruk secara keseluruhan, perlu dilakukan uji konstruk secara individual. dengan melihat nilai muatan faktor dan signifikansi nilai-t. Hasil uji konstruk secara individual menunjukkan adalah bahwa sikap kewirausahaan dapat dijelaskan oleh tiga faktor, yaitu kognitif, afektif dan konasi. Minat berwirausaha dapat dijelaskan oleh lima faktor, yaitu dorongan/motivasi, perhatian, perasaan senang, kemampuan, dan kesesuaian/kecocokan. Perilaku kewirausahaan dapat dijelaskan oleh enam faktor, yaitu faktor kreatif, inovatif, kerjasama, percaya diri, 
pengambilan risiko, dan kepemimpinan, dimana percaya diri merupakan faktor yang paling dominan dalam mengukur hasil belajar. Kemampuan akademik dapat dijelaskan oleh tiga faktor, yaitu Aspek kognitif, afektif dan psikomotorik. hasil belajar dapat dijelaskan oleh empat faktor, yaitu faktor sikap kewirausahaan, minat berwirausaha, perilaku kewirausahaan dan kemampuan akademik, dimana perilaku kewirausahaan merupakan faktor yang paling dominan dalam mengukur hasil belajar.

2) Hasil Uji Keterlaksanaan Model Penilaian Komprehensif Berbasis Proyek Pendidikan Kewirausahaan pada Uji Coba Terbatas

Setelah instrumen uji keterlaksanaan model penilaian ini dinilai pakar dan dinyatakan dapat digunakan, selanjutnya instrumen ini digunakan untuk mengumpulkan data tentang keterlaksanaan model penilaian. Observer yang menilai keterlaksanaan model penilaian ini terdiri dari dua orang observer. Observer dalam pelaksanaan uji coba ini adalah guru ekonomi dan guru kewirausahaan.

Berdasarkan analis, dapat dilihat bahwa nilai rata-rata keterlaksanaan model diperoleh skor 3, berarti termasuk dalam kategori baik. Dengan kategori tersebut berarti model penilaian komprehensif berbasis proyek pendidikan kewirausahaan setelah dilakukan revisi dapat digunakan.

c. Hasil Uji Coba Luas

Uji coba luas, dilaksanakan di SMKN I Depok, SMKN I Pengasih, dan SMK Muhammadiyah 2 Bantul. Uji coba dilaksanakan selama tiga kali pertemuan, tiap pertemuan selama 2 jam pelajaran. Hasil analisis data pada uji coba luas akan dipaparkan pada uraian berikut.

1) Uji Konstruk Model Penilaian Komprehensif Berbasis Proyek Pendidikan Kewirausahaan Pada Uji Coba Luas

Setelah dilakukan uji konstruk dalam uji coba terbatas, untuk melihat konsistensi dilakukan uji coba luas. Untuk keperluan analisis konstruk dalam uji coba luas, perlu dilakukan langkah-langkah seperti berikut: 
a) Perancangan model Second Order Confirmatory Factor Analysis (CFA) Pada Uji Coba Luas

Untuk keperluan uji konstruk instrumen model penilaian komprehensif berbasis proyek pendidikan kewirausahaan dirancang model Second Order Confirmatory Factor Analysis (CFA) seperti dalam uji coba terbatas. Untuk memperoleh data yang terpercaya diperlukan instrumen yang valid dan reliabel. Guna memenuhi hal tersebut, instrumen yang sudah dikembangkan tersebut perlu diuji validitas konstruknya. Untuk validitas konstruk, secara teoretis sudah dilakukan dalam proses pengembangan instrumen, yaitu dengan mengembangkan definisi operasional berdasarkan teori sampai dengan penulisan kisi-kisi dan instrumen penelitian seperti dalam uji coba terbatas. Namun demikian, guna memenuhi validitas konstruk secara empiris, perlu dilakukan pengujian dengan menggunakan model Second Order Confirmatory Factor Analysis (CFA) dan dianalisis dengan menggunakan model SEM. Penggunaan analisis SEM memerlukan beberapa persyaratan yang harus dipenuhi terlebih dahulu, yaitu data berdistribusi normal dan identifikasi model.

b) Pengujian Persyaratan Analisis Model SEM pada Uji Coba Luas Penggunaan analisis SEM memerlukan beberapa persyaratan yang harus dipenuhi terlebih dahulu, yaitu:

\section{(1) Normalitas sebaran data pada Uji Coba Luas}

Penggunaan analisis SEM mensyaratkan bahwa distribusi data memiliki pola sebagaimana distribusi normal. Oleh karena itu, sebelum dilakukan analisis perlu diuji terlebih dahulu normalitas sebaran data untuk masing-masing variabel. Pengujian dilakukan dengan menggunakan model yang dikembangkan oleh Kolmogorov-Smirnov. Hasil uji normalitas sebaran data menunjukkan bahwa nilai signifikansi (p) dari uji Kolmogorv-Smirnov untuk semua variabel lebih dari 0,05. Dengan demikian, dapat disimpulkan bahwa semua variabel memiliki data yang berdistribusi normal. 


\section{(2) Identifikasi Model pada Uji Coba Luas}

Sebelum dilakukan tahap pendugaan parameter untuk mencari solusi dari persamaan simultan yang mewakili model yang dispesifikasikan, pemeriksaan identifikasi dari persamaan simultan tersebut harus diperiksa terlebih dahulu apakah model yang terbentuk berupa model under identified, just identified atau over identified. Pengidentifikasian model tersebut dapat dilihat dari derajat bebas yang ditemukan. Hasil analisis menunjukkan bahwa derajat bebasnya adalah, 115 yang artinya over identified. Oleh karena itu, model ini telah memenuhi syarat untuk dilakukan pengujian lebih lanjut.

c) Hasil Uji Model Penilaian Komprehensif Berbasis Proyek Pendidikan Kewirausahaan Terintegrasi Di SMK.

Untuk dapat melakukan penafsiran terhadap parameter yang ditemukan, terlebih dahulu harus dilihat goodness of fit dari model yang akan diuji. Hipotesis yang diuji adalah model yang dikembangkan dalam penelitian ini fit dengan model yang diperoleh dari data empiris. Berdasarkan persamaan teoretis tersebut, kemudian dilakukan pengujian secara empiris terhadap data dengan menggunakan analisis persamaan struktural (Structural Equation Model). Untuk menentukan fit tidaknya model digunakan kriteria seperti dalam uji coba terbatas.

Berdasarkan hasil pengujian model persamaan struktural ditemukan hasil seperti yang tercantum dalam tabel berikut.

Tabel 2. Hasil Pengujian Goodness of Fit pada Uji Coba Luas

\begin{tabular}{|l|r|r|l|}
\hline \multicolumn{1}{|c|}{ Ukuran } & Nilai & Kriteria & Kesimpulan \\
\hline Chi Square & 117,72 & & \\
\hline p-value & 0,41 & $>0,05$ & Fit \\
\hline RMSEA & 0,01 & $<0,08$ & Fit \\
\hline GFI & 0,93 & $>0,90$ & Fit \\
\hline AGFI & 0,90 & $>0,90$ & Fit \\
\hline
\end{tabular}


Pengujian model Second Order CFA yang ditunjukkan pada tabel di atas menunjukkan bahwa $\mathrm{p}$ value Chi-Square $=0,32>0.05$ GFI $=0,94>0,90$, AGFI 0,91 > 0,90 dan RMSEA $0,02<0,080$. Keempat ukuran kecocokan tersebut menunjukkan bahwa model teoretis yang dihipotesiskan pada penelitian ini cocok (fit) dengan model yang diperoleh dari data empiris sehingga langkah selanjutnya adalah menafsirkan hasil pengujian koefisien muatan faktor/konstruk dalam model Second Order CFA ini. Hasil model empiris dari model CFA pada uji coba luas dapat dilihat pada Gambar 3. di bawah ini.

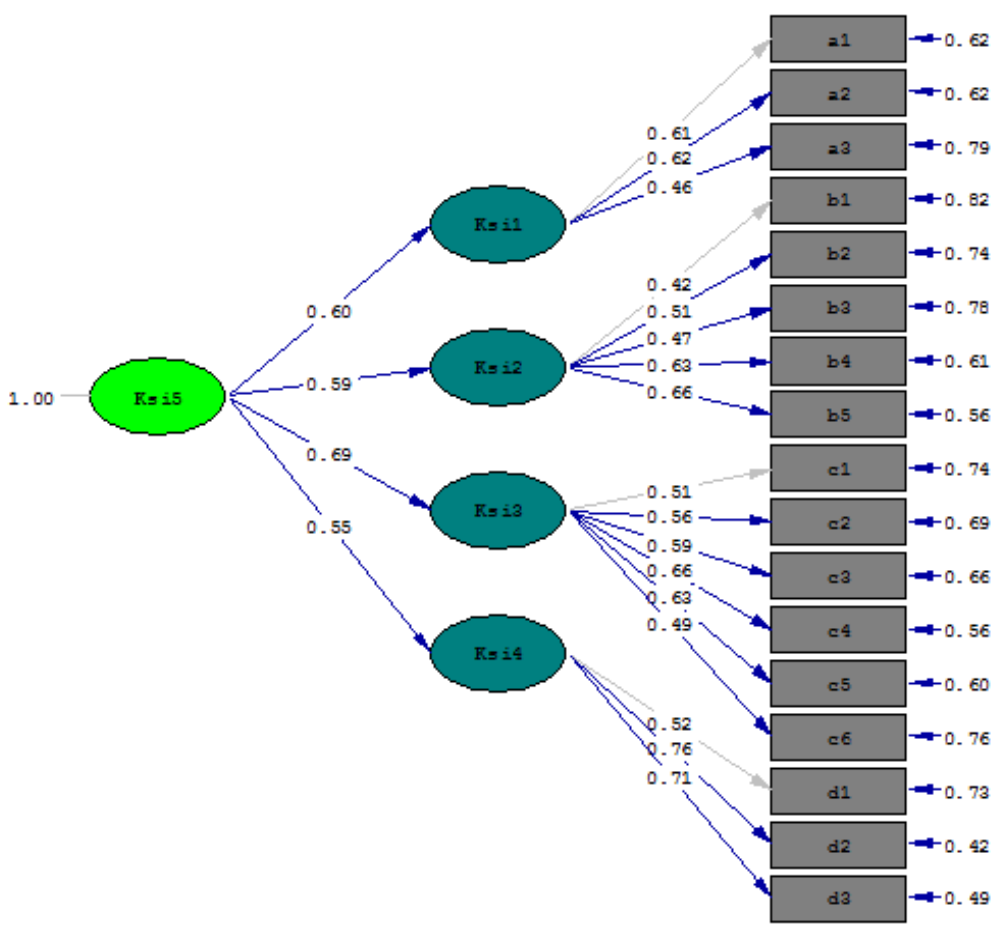

Gambar 3. Model Second Order CFA Empiris pada Uji Coba Luas 
Setelah dilakukan uji konstruk secara keseluruhan, perlu dilakukan uji konstruk secara individual. Hasil uji konstruk secara individual menunjukkan bahwa muatan faktor afektif merupakan faktor yang paling dominan dalam mengukur sikap kewirausahaan, faktor kesesuaian/kecocokan memiliki nilai muatan faktor yang paling besar dalam mengukur minat berwirausaha, muatan faktor percaya diri merupakan faktor yang paling dominan dalam mengukur perilaku kewirausahaan, faktor kemampuan akademik aspek kognitif merupakan faktor yang paling dominan dalam mengukur kemampuan akademik, dan faktor perilaku kewirausahaan merupakan faktor yang paling dominan dalam mengukur hasil belajar.

2) Hasil Uji Keterlaksanaan Model Penilaian Komprehensif Berbasis Proyek Pendidikan Kewirausahaan Pada Uji Coba Luas

Setelah instrumen ini dinilai pakar dan dinyatakan dapat digunakan, selanjutnya instrumen ini digunakan untuk mengumpulkan data tentang keterlaksanaan model penilaian komprehensif berbasis proyek pendidikan kewirausahaan terintegrasi di SMK. Observer yang menilai keterlaksanaan model penilaian ini terdiri dari dua orang observer. Dua orang observer tersebut adalah guru mata pelajaran ekonomi dan guru mata pelajaran kewirausahaan dari SMK yang menjadi subyek penelitian. Berdasarkan hasil analisis data menunjukkan bahwa bahwa nilai rata-rata keterlaksanaan model diperoleh skor 3, berarti termasuk dalam kategori baik (dapat dilaksanakan).

\section{Simpulan}

Berdasarkan hasil análisis data dan pembahasan dapat diambil kesimpulan sebagai berikut:

1. Dilihat dari hasil penilaian pakar, setelah dilakukan revisi model penilaian komprehensif berbasis proyek pendidikan kewirausahaan terintegrasi di SMK dinyatakan baik dan dapat digunakan.

2. Dilihat dari hasil analisis dengan menggunakan model CFA, menunjukkan terjadi konsistensi hasil pengujian model pada uji coba 
Jurnal Penelitian dan Evaluasi Pendidikan

terbatas dan uji coba luas. Hal ini terbukti dari hasil pengujian model pada uji coba terbatas dan uji coba luas sama-sama menghasilkan bahwa model tersebut fit dengan data empiris pada taraf signifikansi $5 \%$.

\section{Daftar Pustaka}

Agapitus H. Kaluge. 2004. Pengembangan Penilaian Proses Belajar Matematika yang Komprehensif dan Kontinu pada Pembelajaran Kooperatif Di SMP. Disertasi doktor. Surabaya: Program Studi Pendidikan Matematika Universitas Negeri Surabaya.

Arman Hakim Nasution., dkk. 2007. Enterpreneurship membangun spirit teknopreneurship. Yogyakarta: ANDI.

Depdiknas. 2003. Undang-Undang RI Nomor 20, Tahun 2003, tentang Sistem Pendidikan Nasional.

Depdiknas. 2006. Undang-Undang RI Nomor 23, tentang Standar Kompetensi Lulusan (SKL).

Engkoswara. 1999. Instructional strategy of civic education at certain school fernandez, h.j.x. measurement scales. Bahan Penataran. Jakarta: Depdiknas.

Gronlund, N. E., \& Linn, R. L. 1990. Measurement and evaluation in teaching 6th ed. New York: Macmillan.

Meredith, George. 2002. Kewirausahaan teori dan praktek. Jakarta: PPM

Mackeracher. 1996. dalam hasil penelitiannya yang berjudul Project Based Learning and Assessment: A Resource Manual for Teachers. New York : McGraw-Hill Book Company.

Nitko, A.J. 1996. Curriculum-based assessment aorkshop papers. Jakarta: Directorate of General of Primary and Secondary Education

Suryana. 2006. Kewirausabaan pedoman praktis: Kiat dan proses menuju sukses. Bandung: PT Salemba Empat

490 - Jurnal Penelitian dan Evaluasi Pendidikan Tahun 16, Nomor 2, 2012 
Suyanto. Juli 1999. Implementasi wawasan entrepreneurship dalam kegiatan pembelajaran di perguruan tinggi. Makalah disampaikan dalam Semiloka Wawasan Entrepreneurship IKIP YOGYAKARTA. Yogyakarta.

Thiaragajan, S., Semmel, D. S., \& Semmel, M. L. 1974. Instructional development for training teachers of exceptional children. Minnesota: Indiana University.

Wijayanto, Setyo Hari. 2008. Structural equation modeling dengan LISREL 8.8: Konsep \& Tutorial. Yogyakarta: Graha Ilmu. 